\title{
Clinical Profile of Mid Day Meal Beneficiaries of Primary Schools in Kurukshetra District
}

\author{
${ }^{1}$ Sachdeva Monika, ${ }^{2}$ Davar Vinti \\ ${ }^{I}$ Research Scholar, UGC-JRF, Department of Home Science, Kurukshetra University, Kurukshetra \\ ${ }^{2}$ Chairperson, Department of Home Science, Kurukshetra University, Kurukshetra
}

\begin{abstract}
The various aspects of clinical profile in mid day meal beneficiaries, between the age group of 6-11 years from Kurukshetra district have been studied. One time observational study of five hundred government primary school children was conducted. A qualified medical practitioner was associated for clinical examination of children having mid-day-meal. Clinical symptoms observed were noted in the structured schedule. Observation of clinical signs reveal the anatomical changes due to malnutrition like deficiency disorders for iron, Vitamin A, B-complex, $C$ and D. Symptoms of anemia were observed at a higher rate in girls than boys. Spongy (9.2\%) and bleeding (5.3\%) gums indicating Vitamin C deficiency was recorded in few subjects. Bones were found normal except few children who were diagnosed with distal wrist/ bowed legs/ pigeon chest. However, the prevalence of these nutritional deficiency disorders may be attributed to their poor nutritional status. Nutrition intervention in the form of supplementation and education in primary schools along with families, teachers and communities has to be strengthened to effectively address malnutrition.
\end{abstract}

Key Words: Clinical Signs, Mid-Day-Meal, Malnutrition

\section{Introduction:}

Malnutrition continues to be a primary cause of ill health and mortality among children in developing countries. It is a major public health problem and accounts for about half of all child deaths worldwide. About 150 million children in developing countries are still malnourished and more than half of underweight children live in South East Asia Region (SEAR). India has made remarkable growth in economic sector and substantial progress in human development but still the manifestations of malnutrition are at unacceptable levels. In spite of the fact that 20 per cent of world's child population lives in India, our country is home to 40 per cent of world's malnourished children (UNICEF, 2004). Survey conducted by 'National Nutrition Monitoring Bureau' has revealed that protein energy malnutrition and other deficiency diseases are prevalent in large proportion in Indian population. More than 75 per cent of the children are suffering from one or the other nutritional deficiency disorders like vitamin deficiency disorder, iron deficiency disorder, iodine deficiency disorder and other non-nutritional diseases. Children suffer from malnutrition, poor health, growth retardation and destitution due to inadequate nutrition, poverty and ignorance of the parents and other environmental factors. Kadam et al (1984) reported that younger the child when malnourished the more apt he is to sustain retardation in physical growth and mental development.

The nutritional status of school going children in the general population is far from satisfactory, so they have become the focus of organized medical and social welfare activities. It is widely accepted that for practical purposes clinical examination is a useful tool for assessing health and nutritional status. Clinical assessment is important for assessing the levels of health of individuals as influenced by the diet consumed. Clinical deficiency signs relate directly to the inadequate nutrition that can be seen or felt in superficial epithelial tissues, especially skin, eyes, hair and buccal mucosa (Jellife, 1966). With this recommendation in mind, the present study was planned to investigate the prevalence of clinical signs among mid day meal beneficiaries of Kurukshetra District of Haryana.

\section{Methodology:}

The study was conducted in rural primary schools of Kurukshetra District of Haryana. Five hundred Mid-Day-Meal beneficiaries in the age group of 6 to 11 years were selected for the study based on random sampling. One time observational cross sectional study was conducted to evaluate the clinical signs and nutritional deficiency in children. Observation of clinical signs reveal the anatomical changes due to malnutrition like deficiency disorders for Vitamin A, B- Complex, C \& D ; deficiency disorders for minerals like iron as described by Jellife, 1966. The symptoms observed were noted in the structured schedule in the presence of qualified medical practitioner. Permission was obtained from school authorities for conducting study. The data collected were recorded with respect to sex of the children and analyzed using SPSS 12. 


\section{Research Findings And Discussion:}

For assessment of clinical profile of mid-day meal beneficiaries, it is of paramount importance to present the age and sex wise distribution of children, which has been depicted in Table - I .

Out of 500 mid day meal beneficiaries, $258(51.6 \%)$ were boys and $242(48.4 \%)$ were girls. Maximum number of subjects 37.5 per cent were in the age group of $8-9$ years followed by 31.9 per cent children in 10 11years group while 30.6 per cent respondents belonged to 6-7 years age group respectively.

Table - 1: Age and Sex wise Distribution of Children $\quad(\mathrm{N}=500)$

\begin{tabular}{|c|c|c|c|c|}
\hline Age (years) & Boys (\%) & Girls (\%) & & Total (\%) \\
\hline $6-7$ & $83(32.2)$ & \multirow{2}{*}{$70(28.9)$} & & $153(30.6)$ \\
\hline $8-9$ & $90(34.9)$ & & & 187 (37.5) \\
\hline $10-11$ & $85(32.9)$ & $75(31.0)$ & & $160(31.9)$ \\
\hline \multirow[t]{2}{*}{ Total } & $258(100)$ & $242(100)$ & & $500(100)$ \\
\hline & \multicolumn{2}{|c|}{ Table - 2: General Profile of the Beneficiaries } & \multicolumn{2}{|c|}{$(\mathrm{N}=\mathbf{5 0 0})$} \\
\hline Clinical Sign & Category & $\begin{array}{l}\text { Boys } \\
\mathrm{n}(\%)\end{array}$ & $\begin{array}{l}\text { Girls } \\
\mathrm{n}(\%)\end{array}$ & $\begin{array}{l}\text { Total } \\
\mathrm{n}(\%)\end{array}$ \\
\hline \multirow[t]{4}{*}{ General appearance } & Good & $57(22.1)$ & $49(20.2)$ & $106(21.2)$ \\
\hline & Fair & $65(25.2)$ & $59(24.4)$ & $124(24.8)$ \\
\hline & Poor & $78(30.2)$ & $76(31.4)$ & $154(30.8)$ \\
\hline & Very Poor & $58(22.5)$ & $58(24.0)$ & $116(23.3)$ \\
\hline \multirow[t]{4}{*}{ Hair } & Normal & $60(23.3)$ & $61(25.2)$ & $121(24.3)$ \\
\hline & Loss of Luster & $72(28.0)$ & $71(29.3)$ & 143 (28.7) \\
\hline & Discolored \& Dry & $65(25.2)$ & $54(22.3)$ & 119 (23.8) \\
\hline & Sparse \& Brittle & $61(23.6)$ & $56(23.1)$ & 117 (23.4) \\
\hline \multirow[t]{3}{*}{ Skin } & Normal & $96(37.2)$ & $85(35.1)$ & $181(36.1)$ \\
\hline & Lack of luster & $75(29.1)$ & 77 (31.8) & $152(30.5)$ \\
\hline & Dry \& Rough & $87(33.7)$ & $80(33.0)$ & $167(33.4)$ \\
\hline \multirow[t]{4}{*}{ Teeth } & Normal & 54 (20.9) & $42(17.4)$ & $96(19.2)$ \\
\hline & Chalky teeth & $78(30.2)$ & $80(33.0)$ & $158(31.6)$ \\
\hline & Discolored & $81(31.4)$ & $75(31.0)$ & $156(31.2)$ \\
\hline & Mottled enamel & 45 (17.4) & 45 (18.6) & $90(18.0)$ \\
\hline
\end{tabular}

(Ref: FAO/WHO Expert Committee on Medical Assessment of Nutritional status, WHO Tech., Rep., Ser. 258) (Figures in parentheses indicate percentage)

Table 2 brings out a picture of general profile of primary school children. Assessment of general appearance indicated that 21.2 per cent of the studied children were in good condition, 24.2 per cent fair, 30.8 per cent poor, and 23.3 per cent very poor.

Normal hair were observed among 24.3 per cent of the respondents. However, 28.7 per cent had dull hair or hair without luster. Approximately equal number of subjects had discolored and dry hair (23.8\%) and 23.4 per cent had sparse and brittle hair. A not so encouraging hair condition of the children indicates a significant deficiency of protein and Vitamin A. Harris et al. (1996) reported forty one percent of Tibetan children who suffered from protein deficiency showed hair depigmentation with both thinness and blonding of the hair.

The skin appeared normal in 36.1 per cent, lusterless in 30.5 per cent and dry and rough in 33 per cent of subjects. The reasons contributing to skin problems could be due to lower intake of fats, $\beta$-Carotene and ascorbic acid.

About 31 per cent of the children had chalky teeth which could be a result of calcium deficiency. Around one third subjects showed discolored teeth visibly due to loss of enamel. Mottled enamel was found in 18 per cent of the subjects indicating fluorosis. The results are substantiated by a study of Pant and Solanki (1989) among underprivileged 8 to 12 year old school boys where dental caries were commonly observed in 24 percent subjects. 
Table - 3: Prevalence of Signs of Deficiency Disorder $\quad(N=500)$

\begin{tabular}{cccc}
\hline Deficiency signs & $\begin{array}{c}\text { Boys } \\
\mathrm{n}(\%)\end{array}$ & $\begin{array}{c}\text { Girls } \\
\mathrm{n}(\%)\end{array}$ & $\begin{array}{c}\text { Total } \\
\mathrm{n}(\%)\end{array}$ \\
\hline Dry conjuctiva & $56(21.7)$ & $53(21.9)$ & $109(21.8)$ \\
Follicular keratosis & $29(11.2)$ & $35(14.5)$ & $64(12.9)$ \\
Stomatitis & $19(7.4)$ & $26(10.7)$ & $45(9.0)$ \\
Cheilosis & $35(13.5)$ & $49(20.2)$ & $84(16.8)$ \\
Magenta tongue & $25(9.7)$ & $32(13.2)$ & $57(11.4)$ \\
Spongy gums & $25(9.7)$ & $21(8.7)$ & $46(9.2)$ \\
Bleeding gums & $15(5.8)$ & $12(4.9)$ & $27(5.3)$ \\
Distal wrist & $9(3.6)$ & $3(1.2)$ & $12(2.4)$ \\
Bowed Legs & $3(1.2)$ & $2(0.8)$ & $5(1.0)$ \\
Pigeon chest & $2(0.8)$ & $1(0.4)$ & $3(0.6)$ \\
\hline
\end{tabular}

(Figures in parentheses indicate percentage)

Table -3 depicts the rate of prevalence of various deficiency signs among the primary school children.

Examination of eye indicated evident dry conjunctiva in 21.8 per cent of subjects and follicular keratosis in 12.9 per cent of subjects . Very well understood functions of Vitamin A are maintenance of visual process and health of epithelial tissues. In the absence of adequate Vitamin A intake, the outer lining of the eyeball loses its usual moist white appearance and becomes dry and wrinkled, and inflammation of the eye may follow. Cornea may loose its transparency and become opaque and soft and may lead to blindness. The skin may become lusterless and dry, finally pigmented and horny. Chary (2000) attributed Vitamin A deficiency among the sample children to the lower consumption of Vitamin A rich foods.

Stomatitis, cheilosis and magenta tongue are considered the deficiency signs of Vitamin B. Stomatitis was found to prevail among 9 per cent subjects with pain in the mouth and difficulty in swallowing. Almost 16.8 per cent subjects showed signs of cheilosis as painful inflammation and cracking at the corner of the mouth and 11.4 per cent of cases had magenta tongue respectively. Presence of similar Vitamin B complex deficiency signs were also reported by Chandrasekhar and George (1991) and Rao et al. (2005) in their respective studies. Some of the clinical symptoms attributed to inadequate intake of riboflavin in the diet are angular stomatitis, scaliness of the skin of the region between the nose and angles of the lips and scrotal dermatitis (ICMR, 2010, Recommended Daily Intakes for Indians, New Delhi).

Spongy gums were observed in 9.2 per cent subjects and bleeding gums in 5.3 per cent. Prevalence of such deficiency signs could be either due to complete lack of or insufficient intake of vegetables and fruits resulting in Vitamin C deficiency.

Enlargement of the distal wrist was noted in 2.4 per cent of the studied children. However, bowed legs and pigeon chest were also observed in very few children indicating deficiency of Vitamin D.

\begin{tabular}{|c|c|c|c|}
\hline Clinical Signs & $\begin{array}{l}\text { Boys } \\
\text { n (\%) }\end{array}$ & $\begin{array}{c}\text { Girls } \\
\text { n (\%) }\end{array}$ & $\begin{array}{l}\text { Total } \\
\mathrm{n}(\%)\end{array}$ \\
\hline Pale Skin & $98(37.9)$ & $119(49.1)$ & $217(43.5)$ \\
\hline Spoon Shaped Nails & $68(26.5)$ & $73(30.1)$ & $141(28.2)$ \\
\hline Pale Nails & $121(46.9)$ & $153(63.2)$ & $274(55.1)$ \\
\hline Tiredness & $76(29.4)$ & $134(55.3)$ & $210(42.3)$ \\
\hline Breathlessness & $68(26.3)$ & $92(38.0)$ & $160(32.1)$ \\
\hline Giddiness & 43 (16.6) & 75 (30.9) & $118(23.7)$ \\
\hline
\end{tabular}

(Ref: Gibson 1990)

(Figures in parentheses indicate percentage)

The data on prevalence of iron deficiency signs has been shown in Table 4. Majority of the subjects were noticed to have pale skin (43.5) and pale nails (55.1). Girls felt breathlessness (38.0) and tiredness (55.3) very easily and frequently as compared to boys. Giddiness was also reported by 23.7 per cent subjects. The prevalence of all these iron deficiency signs could be related to anemia. Prevalence of anemia at a high rate among primary school going children was also reported by Jain et. al. (2000), Rao et al. (2005) and Joseph et. al. (2010). Jain et. al. (2000) attributed various factors like weaning at proper age and iron supplementation as significant in lowering the prevalence of anemia in children.

Rao et. al. (1984) reported that the major problems of 6-14 years age group were those of vitamin deficiencies, anemia, dental caries, and common infections of skin, scalp and eyes. Angular stomatitis, xerosis, pale conjuctiva were the main deficiency signs. According to Kamalingaswami (1992) deficiencies of iron, iodine and Vitamin A are considered to be a public health problem worldwide. 


\section{Conclusion}

All these observations among 6 - 11 years old mid-day-meal beneficiaries of Kurukshetra district on clinical profile of the children revealed that out of total children screened (500) prevalence of anemia was higher in girls than boys. The reason which could be attributed to this higher prevalence, researchers feel could only be in the low quality of diet and care being given to girls in homes. All other deficiency signs were equally present in both the sexes. The general level of health was found to be average in studied children.

At the end we may say that mid-day-meal programme is a massive social welfare programme aiming at attracting children in to the educational main stream and also providing them with all the much needed supplementary nutrition to make them healthy and worthy citizens of the country.

\section{References:}

[1] Chandrasekhar, U. and George, B. (1991). Prevalence of vitamin A deficiency in children from selected village of Coibatore and Periyar districts. Res. High. JADU, 1(3) : 211-214.

[2] Chary, K.B. (2000). Food based strategy for combating vitamin A deficiency. Nutrition News, 21:1. National Institute of Nutrition, HYDERABAD, A.P. (India).

[3] FAO/WHO Expert Committee on Medical Assessment of Nutritional status, WHO Tech., Rep., Ser. 258

[4] Gibson, R.S., (1990). Principles of Nutritional Assessment. Oxford University Press, New York, Oxford, 257:577-855.

[5] Harris, N.S., Yangzom, Y., Pinzo, L., Gyaltsen, P. and Crawford P.B. (1996). Effects of age, comunity location and illness on nutritional status of high altitude Tibetan Children. International Child Health : A Digest of current information, October 1996, 7(4).

[6] Indian Council of Medical Research, (2010). Nutrient Requirement and Recommended Dietary Allowances for Indians. NIN. Hydrabad, pp: 67-89.

[7] Jain, S., Chopra, H., Garg, S.K., Bhatnagar, M. and Singh, J. V. (2000). Anemia in children : Early iron supplementation. Indian J. Pediatr., 67 (1) : 19-21.

[8] Jellife, D.B. (1996). The assessment of nutritional status of the community. WHO Monograph Series No. 53, WHO, Geneva, Switzerland, I p.

[9] Joseph, N., Subba, S.H., Naik, V.A., Mahanta, N.S. and Mallapur, M.D. (2010). Indian J. Pediatr, 77(4) : 456-458.

[10] Kadam, SS., Sulankhe, DK., Jadhav, SJ. and Raje-Bhonsle, KI. (1984). : Brain development intelligence and behaviour. The Indian Journal of Nutritional dietetics. 21(1) : 69-78.

[11] Kamalingaswami, VC. (1992). Opportunities one vitamin, two minerals. World health forum 13:222-223.

[12] Pant, I. and Solanki, K. (1989). Assessment of health and nutritional status of under privileged school age boys (8-12years) with special emphasis on vitamin A deficiency. Nutr. Soc. India 82.

[13] Rao, NP., Singh, D., Krishna, TP. and Nayar, S (1984). Health and nutritional status of rural primary school children. Ind. Pediatr. $21: 777-783$.

[14] UNICEF (2004). State of Worlds Children, UNICEF. 